\title{
Opłata miejscowa i uzdrowiskowa na przykładzie gmin województwa kujawsko-pomorskiego
}

\section{Local and spa fee on the example of Kujawsko-pomorskie municipalities}

Streszczenie. Artykuł został poświęcony omówieniu fakultatywnych danin publicznych obowiązujących w polskim systemie podatkowym - tj. opłaty miejscowej oraz opłaty uzdrowiskowej. W publikacji przedstawiono konstrukcję prawną obu opłat zgodnie z regulacjami zawartymi w ustawie z dnia 12 stycznia 1991 roku o podatkach i opłatach lokalnych oraz przedstawiono wyniki badań empirycznych, które zostały przeprowadzone w gminach województwa kujawsko-pomorskiego posiadających opłatę miejscową i uzdrowiskową. Podstawowym celem badania było ustalenie, w których gminach województwa analizowane opłaty obowiązywały w latach 2010-2014 oraz jakie dochody z tytułu pobierania tych opłat osiągnęły poszczególne samorządy gminne. Zrealizowane badanie miało także odpowiedzieć na pytanie, czy analizowane opłaty są w ogóle opłacalne z punktu widzenia organów samorządu terytorialnego. Artykuł powstał 
w oparciu o analizę aktów prawnych, dostępnej literatury przedmiotu oraz przy wykorzystaniu orzecznictwa sądów administracyjnych. Ponadto autorzy przedstawili wyniki badań empirycznych, które stanowiły istotną część pracy magisterskiej mgr Iwony Majewskiej.

Słowa kluczowe: opłaty lokalne; opłata miejscowa; opłata uzdrowiskowa.

Abstract. The article discusses facultative public levies in the Polish tax system - ie. local and spa tax. This publication presents legal structure of both taxes in accordance with the regulations of local taxes and fees contained in the Act of 12 January 1991. It also presents the results of empirical researches that have been carried out in Kujawsko-pomorskie municipalities, where local and spa taxes occured. The basic aim of study was to determine in which municipalities these fees were in force in 2010-2014 and what income had the individual municipal governments. Completed research would answer the question, whether the analysed charges are effective from local government`s point of view. The article is based on the analysis of legal acts, available literature and using case law of administrative courts. Furthermore, the authors presented the results of empirical research taken from Ms. Iwona Majewska thesis.

Keywords: local fees; local tax; spa fee.

\section{Wprowadzenie}

Gminy mające korzystne właściwości klimatyczne, walory krajobrazowe lub mające na swoim terenie obszary, którym nadano status ochrony uzdrowiskowej lub status uzdrowiska, mogą wprowadzać i pobierać tzw. opłaty klimatyczne. Pojęcie to obejmuje w obecnym stanie prawnym dwie fakultatywne daniny publiczne ${ }^{1}$ : opłatę miejscową i uzdrowiskową, które uregulowane zostały przez ustawodawcę w art. 17 ustawy z dnia 12 stycz-

1 Zgodnie z art. 5 ust. 2 pkt 1 ustawy z dnia 27 sierpnia 2009 r. o finansach publicznych (tekst jedn.: Dz.U. z 2016 r., poz. 1870) do danin publicznych zalicza się: podatki, składki, opłaty, wpłaty z zysku przedsiębiorstw państwowych i jednoosobowych spółek Skarbu Państwa oraz banków państwowych, a także inne świadczenia pieniężne, których obowiązek ponoszenia na rzecz państwa, jednostek samorządu terytorialnego, państwowych funduszy celowych oraz innych jednostek sektora finansów publicznych wynika $\mathrm{z}$ odrębnych ustaw. 
nia 1991 r. o podatkach i opłatach lokalnych ${ }^{2}$. Obie daniny stanowią dochód własny gminy, co bezpośrednio wynika z ustawy z dnia 13 listopada 2003 r. o dochodach jednostek samorządu terytorialnego ${ }^{3}$. Poniżej przedstawiona zostanie konstrukcja prawna obecnie obowiązującej opłat miejscowej i uzdrowiskowej oraz wyniki badań przeprowadzonych w gminach województwa kujawsko-pomorskiego, w których w latach 2010-2014 obowiązywały uchwały dotyczące wprowadzenia tych opłat na swój teren.

\section{Konstrukcja prawna opłaty miejscowej}

Opłata miejscowa w myśl art. 17 ust. 1 u.p.o.l. pobierana jest od osób fizycznych przebywających dłużej niż dobę w celach turystycznych, wypoczynkowych lub szkoleniowych w miejscowościach posiadających korzystne właściwości klimatyczne, walory krajobrazowe oraz warunki umożliwiające pobyt osób w tych celach, a także w miejscowościach znajdujących się na obszarach, którym nadano status obszaru ochrony uzdrowiskowej na zasadach określonych w ustawie z dnia 28 lipca 2005 r. o lecznictwie uzdrowiskowym, uzdrowiskach i obszarach ochrony uzdrowiskowej oraz o gminach uzdrowiskowych ${ }^{4}-$ za każdy dzień pobytu w takich miejscowościach. Minimalne warunki, jakie powinna spełniać miejscowość, w której można pobierać opłatę miejscową, określa Rada Ministrów w drodze rozporządzenia, uwzględniając zróżnicowanie warunków regionalnych i lokalnych ${ }^{5}$. Obecnie obowiązuje rozporządzenie Rady Ministrów z dnia 18 grudnia 2007 r. ${ }^{6}$

Właściwa rada gminy, podejmując stosowną uchwałę na mocy upoważnienia zawartego w art. 17 ust. 5 u.p.o.l., ustala miejscowości, które

\footnotetext{
Tekst jedn.: Dz.U. z 2016 r., poz. 716, dalej jako: ,,ustawa” lub u.p.o.l.

Tekst jedn.: Dz.U. z 2016 r., poz. 198 ze zm.

Tekst jedn.: Dz.U. z 2016 r., poz. 879.

Zgodnie z art. 17 ust. 4 u.p.o.l. Rada Ministrów określa w rozporządzeniu m.in. warunki klimatyczne, krajobrazowe oraz warunki umożliwiające pobyt osób w celach turystycznych, wypoczynkowych lub szkoleniowych.

6 Rozporządzenie Rady Ministrów z dnia 18 grudnia 2007 r. w sprawie warunków, jakie powinna spełniać miejscowość, w której można pobierać opłatę miejscową (Dz.U. z 2007 r., Nr 249, poz. 1851).
} 
spełniają określone w rozporządzeniu kryteria i na których terenie będzie się pobierać opłatę miejscową ${ }^{7}$. Uznanie przez radę gminy, że dana miejscowość spełnia warunki niezbędne do poboru opłaty miejscowej, nie jest przypadkowe i dowolne, lecz następuje na podstawie kryteriów określonych w ww. rozporządzeniu, które to kryteria są jednakowe dla każdej miejscowości w kraju ${ }^{8}$. Należy zwrócić uwagę w tym zakresie na wyrok Naczelnego Sądu Administracyjnego z dnia 5 września 1991 r., w którym sąd stwierdził, iż ,uchwała rady gminy dotycząca ustalenia opłaty miejscowej, nie jest uchwałą ważną, jeżeli zostanie uchwalona dla miejscowości, która nie spełnia kryteriów określonych w ustawie o podatkach i opłatach lokalnych oraz w wydanym na jej podstawie rozporządzeniu"”.

W zakresie obowiązywania podmiotowego należy wskazać, że omawiana opłata obciąża jedynie osoby fizyczne, które przebywają dłużej niż dobę w miejscowościach, w których pobiera się opłatę miejscową, w celach turystycznych, wypoczynkowych lub szkoleniowych, a także w miejscowościach mających status ochrony uzdrowiskowej. Opłata miejscowa związana jest z pobytem w konkretnej miejscowości, a nie z pobytem na terenie gminy, w której położona jest ,szczególna” miejscowość. Opłata miejscowa $\mathrm{w}$ związku z powyższymi uwagami pobierana jest za każdy dzień pobytu, niezależnie od długości jego trwania, pod oczywistym warunkiem, że pobyt trwa dłużej niż dobę ${ }^{10}$. W orzecznictwie wskazuje się, że pod pojęciem doby należy rozumieć dzień kalendarzowy ${ }^{11}$. Odmienny pogląd prezentuje doktryna prawa podatkowego. R. Dowgier wskazuje, że prawidłowa wykładania art. 17 prowadzi do wniosku, że obowiązek uiszczenia opłaty miejscowej lub uzdrowiskowej powstaje po upływie doby pobytu, rozumianej jako kolejne 24 godziny ${ }^{12}$.

\footnotetext{
A. Olesińska, Polskie prawo podatkowe. Zarys ogólny, Toruń 2007, s. 424.

A. Sienkiewicz, Opłata miejscowa, „Biuletyn Skarbowy” 2008, nr 1, s. 12.

A. Borodo, Polskie prawo finansowe. Zarys ogólny, Toruń 2007, s. 187.

W. Morawski, J. Wantoch-Rekowski, Komentarz do art. 17 ustawy o podatkach i opłatach lokalnych, [w:] W. Morawski (red.), Ustawa o podatkach i opłatach lokalnych. Komentarz, Gdańsk 2013, s. 467.

Wyrok WSA w Bydgoszczy z dnia 27 kwietnia 2011 r., I SA/Bd 76/11, CBOSA.

12 R. Dowgier, Obowiqzek uiszczenia opłaty uzdrowiskowej. Glosa do wyroku WSA w Bydgoszczy z 27 kwietnia 2011 roku (I SA/Bd 76/11), „Finanse Komunalne” 2011, nr 7-8, s. 121.
} 
Przepisy prawne dotyczące zakresu podmiotowego opłaty miejscowej czasami mogą być podstawą merytorycznie uzasadnionych dyskusji. Jak wskazuje P. Borszowski: „(...) problem może powstać wówczas, gdy osoba fizyczna w ramach realizowania obowiązków zawodowych będzie przebywać w konkretnych miejscowościach na szkoleniu.” Autor stwierdza, że „(...) w sytuacji, gdy szkolenie nie jest związane z wykonywaniem konkretnych obowiązków pracowniczych, nie ulega wątpliwości, że - po spełnieniu pozostałych warunków - powstaje obowiązek poboru opłaty miejscowej”. Co w sytuacji, gdy szkolenie jest jednym z elementów, które podnoszą kwalifikacje pracownicze, i pracownik musi wyjechać w związku z szkoleniem do miejscowości, w której obowiązuje opłata miejscowa? P. Borszowski przyjmuje w takich sytuacjach pogląd, że należy doszukiwać się, w ramach takiego wyjazdu, wyłącznie celu szkoleniowego, którego nie można wiązać z pracą zawodową ${ }^{13}$. Warto także zwrócić uwagę, rozważając powyższe kwestie, na wyrok WSA w Szczecinie z dnia 6 października 2005 r. ${ }^{14}$, w którym sąd wskazał, że „,nie powinno się pobierać opłaty miejscowej od osób, które odbywają w danej miejscowości szkolenie i jednocześnie w tej samej miejscowości świadczą pracę”.

Ustawodawca w art. 17 ust. 2 ustawy prezentuje katalog zwolnień o charakterze podmiotowym, w którym określono, iż opłaty miejscowej oraz opłaty uzdrowiskowej nie pobiera się od:

1. członków personelu przedstawicielstw dyplomatycznych i urzędów konsularnych oraz innych osób zrównanych z nimi na podstawie ustaw, umów lub zwyczajów międzynarodowych, jeżeli nie są obywatelami polskimi i nie mają miejsca pobytu stałego na terytorium Rzeczypospolitej Polskiej - pod warunkiem wzajemności,

2. osób przebywających w szpitalach,

3. osób niewidomych i ich przewodników,

4. podatników podatku od nieruchomości z tytułu posiadania domów letniskowych położonych w miejscowości, w której pobiera się opłatę miejscową albo uzdrowiskową,

13 P. Borszowski, Ustawa o podatkach i opłatach lokalnych. Komentarz, Warszawa 2011, s. 237-238.

14 Sygn. I SA/Sz 362/05, CBOSA. 
5. zorganizowanych grup dzieci i młodzieży szkolnej.

Powyższy katalog ma charakter wyczerpujący i jest jedynym przewidzianym przez ustawodawcę katalogiem zwolnień podmiotowych. Ponadto na podstawie art. 19 ust. 3 u.p.o.l. rada gminy może w drodze uchwały wprowadzić inne niż wymienione w ustawie zwolnienia przedmiotowe. $Z$ tego przepisu wynika, że rada gminy nie może wprowadzać innych zwolnień podmiotowych, gdyż te zgodnie z art. 217 Konstytucji wymagają formy ustawowej ${ }^{15}$.

Warto również wskazać na przepis art. 17 ust. 2a u.p.o.l., który stanowi, że od osób, od których pobiera się opłatę uzdrowiskową, nie pobiera się opłaty miejscowej. Jak podkreśla P. Borszowski: „(...) opłata uzdrowiskowa niejako pochłania opłatę miejscową, stąd też ustawodawca wyklucza w ww. artykule możliwość nakładania obu opłat jednocześnie”16. Pierwszeństwo opłaty uzdrowiskowej wynika, nie tylko z uwagi na wysokość stawki, ale także z faktu, że teren będący uzdrowiskiem posiada korzystniejsze warunki klimatyczne i walory krajobrazowe niż obszary, które nie otrzymały statusu uzdrowiska ${ }^{17}$.

Stawki dzienne opłaty miejscowej ustawodawca określił w art. 19 pkt 1 lit. b) i c) u.p.o.l., z tym że opłaty te należne są za każdy dzień pobytu pod warunkiem, że pobyt trwa dłużej niż dobę. Zgodnie z art. 20 ust. 1 ustawy górne granice stawek kwotowych określonych w art. 19 pkt 1 i obowiązujących w danym roku podatkowym ulegają corocznej zmianie na następny rok podatkowy w stosunku odpowiadającym wskaźnikowi cen towarów i usług konsumpcyjnych w okresie pierwszego półrocza roku, w którym stawki ulegają zmianie w stosunku do analogicznego okresu roku poprzedniego ${ }^{18}$. Górne granice stawek kwotowych podatków i opłat lokalnych ogłaszane są w drodze obwieszczenia ministra właści-

\footnotetext{
W. Morawski, J. Wantoch-Rekowski, Komentarz do art. 17 ustawy..., s. 468.

P. Borszowki, Ustawa o podatkach i opłatach lokalnych. Komentarz..., s. 241.

G. Dudar, Komentarz do art. 17 ustawy o podatkach i opłatach lokalnych, [w:] L. Etel, S. Presnarowicz, G. Dudar, Podatki i opłaty lokalne. Podatek rolny. Podatek leśny. Komentarz, Warszawa 2008, s. 415.

18 Wskaźnik cen ustalany jest na podstawie komunikatu Prezesa Głównego Urzędu Statystycznego ogłoszonego w Dzienniku Urzędowym Rzeczypospolitej Polskiej „Monitor Polski” w terminie 20 dni po upływie pierwszego półrocza.
} 
wego do spraw finansów publicznych, które publikowane są w Dzienniku Urzędowym Rzeczypospolitej Polskiej „Monitor Polski”. Zgodnie z obecnie obowiązującym obwieszczeniem Ministra Finansów ${ }^{19}$ stawka opłaty miejscowej w miejscowościach, które posiadają korzystne właściwości klimatyczne, walory krajobrazowe oraz warunki umożliwiające pobyt osób fizycznych w celach turystycznych, wypoczynkowych lub szkoleniowych, nie może przekroczyć 2,18 zł dziennie (w 2017 r. - 2,17 zł dziennie). Natomiast stawka opłaty miejscowej w miejscowościach posiadających status obszaru ochrony uzdrowiskowej nie może przekroczyć 3,10 zł dziennie (w 2017 r. - 3,08 zł dziennie).

\section{Konstrukcja prawna opłaty uzdrowiskowej}

Jeżeli chodzi o opłatę uzdrowiskową, to należy zaznaczyć, że jest ona stosunkowo „młodą” opłatą. Nie jest nową opłatą, lecz została wyodrębniona $\mathrm{z}$ dotychczas obowiązującej opłaty miejscowej ${ }^{20}$. Jej wyodrębnienie wiązało się z wejściem w życie ustawy z dnia 28 lipca 2005 r. o lecznictwie uzdrowiskowym, uzdrowiskach i obszarach ochrony uzdrowiskowej oraz gminach uzdrowiskowych ${ }^{21}$. Ustawodawca w art. 17 ust. 1a u.p.o.l. stanowi, że opłatę uzdrowiskową, podobnie jak miejscową, pobiera się za każdy dzień pobytu od osób fizycznych przebywających dłużej niż dobę w celach zdrowotnych, turystycznych, wypoczynkowych lub szkoleniowych w miejscowościach, którym nadano status uzdrowiska na podstawie ww. ustawy. Cele przebywania osób fizycznych w danej miejscowości są rozszerzone tutaj o cele zdrowotne ${ }^{22}$.

19 Obwieszczenie Ministra Finansów z dnia 5 sierpnia 2015 r. w sprawie górnych granic stawek kwotowych podatków i opłat lokalnych w 2016 r., M.P. z 2015 r. poz. 735.

20 G. Dudar, Opłata uzdrowiskowa - problemy praktyczne, „Przegląd Podatków Lokalnych i Finansów Samorządowych” 2006, nr 6, s. 9.

21 L. Etel, R. Dowgier, Podatki i opłaty lokalne. Czas na zmiany, Białystok 2013, s. 63-64. W uzasadnieniu do projektu ustawy wskazano, że celem zmiany było zapewnienie gminom, na terenie których będą znajdować się uzdrowiska, dochody równoważące koszty związane z uzyskaniem przez gminę potwierdzenia właściwości leczniczych (Sejm RP IV kadencji, druk nr 3636, www.sejm.gov.pl).

22 P. Borszowski, K. Stelmaszczyk, Podatki i opłaty lokalne. Podatek rolny. Podatek leśny. Komentarz, Warszawa 2016, s. 324. 
Miejscowości, w których z tytułu pobytu może być pobierana omawiana opłata, muszą mieć status uzdrowiska przyznany na zasadach określonych w ww. ustawie. Uzdrowiskiem, zgodnie z art. 2 pkt 3 powyższej ustawy, jest obszar, na terenie którego prowadzone jest lecznictwo uzdrowiskowe, wydzielony w celu wykorzystania i ochrony znajdujących się na jego obszarze naturalnych surowców, spełniający warunki, o których mowa w art. 34 ust. 1, któremu został nadany status uzdrowiska. Obszar musi spełniać następujące wymagania: posiada klimat o właściwościach leczniczych i złoża naturalnych surowców leczniczych o potwierdzonych właściwościach leczniczych na zasadach określonych w ustawie; na jego obszarze znajdują się zakłady lecznictwa uzdrowiskowego, spełnia określone w przepisach o ochronie środowiska wymagania w stosunku do środowiska oraz posiada infrastrukturę techniczną w zakresie gospodarki wodno-ściekowej, energetycznej, transportu zbiorowego, a także prowadzi gospodarkę odpadami ${ }^{23}$.

Stawka opłaty uzdrowiskowej uchwalana jest przez radę gminy w drodze uchwały, z tym, że stawka ta zgodnie z art. 19 pkt 1 nie może przekroczyć 4,27 zł dziennie (w 2017 roku - 4,24 zł dziennie). Obowiązująca stawka wynika z wcześniej cytowanego obwieszczenia Ministra Finansów w sprawie górnych granic stawek kwotowych podatków i opłat lokalnych na rok 2016.

Katalog zwolnień zawartych w art. 17 ust. 2 ustawy jest identyczny jak w przypadku opłaty miejscowej. Jednakże w zakresie zwolnień z opłaty uzdrowiskowej warto odnieść się do artykułu J. Wantoch-Rekowskiego, który porusza w nim temat zwolnienia podmiotowego z opłaty uzdrowiskowej osób przebywających w szpitalach uzdrowiskowych. Autor wskazuje, że w środowisku naukowym, ale także w doktrynie trwał spór, którego problemem była interpretacja dwóch zbliżonych do siebie pojęć: „,szpital” oraz „szpital uzdrowiskowy”. Spór ten dotyczy kwestii poboru opłaty od przysłowiowych kuracjuszy, czyli od osób przebywających w szpitalach uzdrowiskowych. J. Wantoch-Rekowski odniósł się w artykule nie tylko do stanowiska doktryny, ale także odwołał się do

23 Tamże, s. 324-325. 
interpretacji ogólnej Ministra Finansów z dnia 3 października 2014 r. ${ }^{24}$, w której podkreślono, że „,(..) w związku z art. 17 ust. 2 pkt 2 u.p.o.l. opłaty uzdrowiskowej nie powinno się pobierać od osób przebywających w szpitalach uzdrowiskowych”. W artykule autor wskazuje, że mimo wydanej interpretacji Ministra Finansów, niektóre organy podatkowe miały problem ze zwolnieniem z tej opłaty tej określonej grupy osób. Problemy z przyjęciem stanowiska Ministra Finansów mieli także przedstawiciele doktryny, którzy mówili, że dla nich „interpretacja Ministra Finansów nic nie zmieniła”. Opisany w artykule problem został jednak w znacznym stopniu rozwiązany, gdyż jak wskazuje autor w podsumowaniu w kontekście szpitali uzdrowiskowych ,interpretacja Ministra Finansów przyczyniła się w znacznym stopniu do niemalże jednolitej wykładni art. 17 ust. 2 pkt 2 ww. ustawy przez organy podatkowe, judykaturę i doktrynę"25.

W zakresie omawianych opłat lokalnych kompetencją rady gminy jest możliwość zarządzenia poboru tych opłat w drodze inkasa, określenie pomiotów będących inkasentami oraz wysokość ich wynagrodzenia za inkaso (art. 19 pkt 2 u.p.o.l.). Ponadto rada gminy może wprowadzić obowiązek prowadzenia przez inkasentów ewidencji osób, o których mowa w art. 17 ust. 1, zobowiązanych do uiszczania opłaty miejscowej oraz określić szczegółowy zakres danych zawartych w tej ewidencji, uwzględniając konieczność zapewnienia prawidłowego poboru opłaty miejscowej.

Zarówno opłata miejscowa, jak i opłata uzdrowiskowa pobierane są, zgodnie z art. 19 pkt 1 u.p.o.l., za każdy dzień pobytu w miejscowościach, na terenie których obowiązuje konkretna opłata, pod warunkiem że pobyt trwa dłużej niż dobę. Szczegółowy tryb poboru, wysokości stawki opłaty oraz terminy jej płatności ustala w drodze stosownej uchwały rada gminy. Obowiązek uiszczenia takiej opłaty zmienia się w zobowiązanie podatkowe z upływem każdego dnia przebywania na terenie, który jest objęty określoną opłatą, wobec czego nie ma możliwości pobierania wymienionych opłat z góry za cały przewidywany pobyt, w pierwszym dniu przy-

24 Dz.Urz. Ministra Finansów z 2014 r. poz. 38.

25 J. Wantoch-Rekowski, Opłata uzdrowiskowa a pobyt w szpitalu uzdrowiskowym uwagi na tle interpretacji ogólnej ministra finansów, „Prawo Budżetowe Państwa i Samorządu" 2016, nr 1, s. 33-41. 
jazdu do danej miejscowości. Nie jest to możliwe, gdyż byłoby to sprzeczne z obowiązującym $\mathrm{w}$ tym zakresie prawem, a co za tym idzie działanie to byłoby nielegalne ${ }^{26}$. Takie rozstrzygnięcie podjęła także Regionalna Izba Obrachunkowa w Olsztynie w uchwale z dnia 26 stycznia 2006 r. $^{27}$, która stwierdziła, że „,(...) w związku z art. 17 ust. 1 pkt 1 oraz art. 19 ust. 1 lit b) u.p.o.l., opłata miejscowa może być pobierana od osób fizycznych przebywających na danym obszarze i w określonych celach (opisanych w ustawie), za każdy dzień pobytu. Z przedstawionego przepisu wynika, że obowiązek uiszczenia tej opłaty przekształca się w zobowiązanie podatkowe wraz z upływem każdego dnia pobytu. Wobec tego nie jest możliwe pobieranie jej z góry pierwszego dnia, za cały pobyt w danej miejscowości”. Warto również podkreślić, że w ocenie kolegium RIO w Olsztynie pobieranie tej opłaty wraz z upływem każdego dnia, mogłoby znacznie utrudnić ściągalność jej wartości szczególnie w hotelach i innych ośrodkach o dużej liczbie miejsc noclegowych i mogłoby to przyczynić się do uszczuplenia dochodów gminy z tego tytułu. Dlatego też opłata miejscowa, o której mowa, w przeciwieństwie do opłaty targowej (która z kolei należy pobierać każdego dnia), może być pobierana po upływie każdego dnia pobytu lub za kilka dni, w trakcie których osoba fizyczna przebywałaby w danej miejscowości, czyli przykładowo ostatniego dnia pobytu za cały okres wizyty w danej miejscowości”.

\section{Opłata miejscowa i uzdrowiskowa w gminach województwa kujawsko-pomorskiego}

Przedmiotem przeprowadzonego badania empirycznego był monitoring funkcjonowania opłaty miejscowej i uzdrowiskowej w gminach oraz miastach województwa kujawsko-pomorskiego. Podstawowym celem badania było ustalenie, w których gminach analizowane opłaty obowiązywały w latach 2010-2014 oraz jakie dochody z tytułu pobierania tych opłat

26 W. Morawski, J. Wantoch-Rekowski, Komentarz do art. 19 ustawy o podatkach i opłatach lokalnych, [w:] W. Morawski (red.), Ustawa o podatkach i opłatach lokalnych. Komentarz, Gdańsk 2013, s. 492-493.

27 Uchwała RIO w Olsztynie Nr IV/42/06 z dnia 26 stycznia 2006 r., LEX nr 195728. 
osiągnęły samorządy gminne. Zrealizowane badanie miało także odpowiedzieć na pytanie, czy analizowane opłaty są w ogóle opłacalne z punktu widzenia organów samorządu terytorialnego.

Terenem przeprowadzonego badania było województwo kujawsko-pomorskie, które powstało 1 stycznia 1999 r. na mocy ustawy z dnia 24 lipca 1998 r. o wprowadzeniu zasadniczego trójstopniowego podziału terytorialnego państwa ${ }^{28}$. Województwo kujawsko-pomorskie składa się z 19 powiatów oraz 4 miast na prawach powiatu (Bydgoszcz, Toruń, Włocławek, Grudziądz). Administracyjnie województwo to podzielone jest na 144 gmin (wiejskich - 92, miejskich - 17, wiejsko-miejskich - 35).

Przed rozpoczęciem badania współautorka artykułu wyróżniła kilka podstawowych problemów badawczych dotyczących funkcjonowania opłaty miejscowej i uzdrowiskowej w gminach województwa kujawsko-pomorskiego, a po przeprowadzonym badaniu chciała znaleźć odpowiedzi na poniższe pytania:

1. w ilu gminach województwa kujawsko-pomorskiego występowała w latach 2010-2014 opłata miejscowa?

2. jakie gminy województwa kujawsko-pomorskiego posiadają opłatę uzdrowiskową i jaki odsetek procentowy te gminy stanowią?

3. jak kształtowały się stawki obu opłat lokalnych w analizowanym okresie?

4. jakie dochody osiągnęły poszczególne gminy województwa kujawsko-pomorskiego z tytułu wpływów do budżetu oraz jaką wartość procentową stanowią te dochody w stosunku do kwoty ogólnego budżetu ?

5. jaką podstawową funkcję pełni w gminach i miastach województwa kujawsko-pomorskiego opłata miejscowa i uzdrowiskowa?

Kolejnym etapem procedury badawczej było określenie hipotez roboczych, które w literaturze przez M. Łobockiego nazywane są „(...) próbą odpowiedzi na sformułowane uprzednio problemy badawcze, przy czym są one świadomie przyjętymi przez badacza przypuszczeniami, wymagającymi potwierdzenia bądź odrzucenia w wyniku przeprowadzo-

28 Dz.U. z 1998 r., Nr 96, poz. 603. 
nych badań”29. Zgodnie z przyjętymi wyżej problemami badawczymi sformułowano kilka hipotez roboczych, które zostały zweryfikowane $\mathrm{w}$ trakcie badania empirycznego:

1. opłata miejscowa funkcjonowała w latach 2010-2014 w mniej niż 10\% gmin województwa kujawsko-pomorskiego.

2. opłatę uzdrowiskową mają wyłącznie gminy o statusie uzdrowiska, a w województwie kujawsko-pomorskim - według wiedzy badaczki tylko Ciechocinek, Inowrocław oraz Brześć Kujawski.

3. stawki opłaty miejscowej i uzdrowiskowej w poszczególnych gminach wykazywały tendencję rosnącą.

4. dochody osiągnięte przez poszczególne gminy w latach 2010-2014 z tytułu omawianych opłat lokalnych nie przekraczały $1 \%$ wszystkich dochodów budżetowych.

5. opłata miejscowa i uzdrowiskowa w gminach województwa kujawsko-pomorskiego pełni jedynie typowe funkcje pozafiskalne.

Metodą badawczą wykorzystaną w badaniu empirycznym była metoda analizy aktów prawa miejscowego podejmowanych przez poszczególne organy stanowiące gmin, które zamieszczone były w Biuletynie Informacji Publicznej badanych gmin (np. uchwały w sprawie stawek opłaty miejscowej) oraz sprawozdań finansowych z wykonania budżetu z analizowanego okresu.

Po przeanalizowaniu Biuletynów Informacji Publicznej poszczególnych gmin i miast województwa kujawsko-pomorskiego oraz stosownych uchwał organów stanowiących tych jednostek ustalono, iż spośród wszystkich jednostek samorządu terytorialnego najniższego szczebla zaledwie 13 z nich miało w latach 2010-2014 na swoim obszarze opłatę miejscową ${ }^{30}$, co stanowi 9,03\% ogółu województwa. W ten sposób po-

29 M. Łobocki, Wprowadzenie do metodologii badań pedagogicznych, Kraków 2007, s. 132.

30 Opłatę miejscową posiadały w latach 2010-2014 następujące jednostki: gmina Tuchola w powiecie tucholskim jedynie w roku 2010, gmina Nowe w powiecie świeckim i gmina Rogowo w powiecie żnińskim w latach 2010-2012, miasto Toruń w latach 2013-2014, w całym analizowanym okresie opłata miejscowa istniała w: gminie Koronowo w powiecie bydgoskim, w gminie Lubiewo w powiecie tucholskim, w gminie Osie w powiecie świeckim, w gminach: Bobrowo i Zbiczno w powiecie brodnickim, 
twierdziła się pierwsza hipoteza robocza, w której badaczka założyła że w funkcjonowanie opłaty miejscowej w gminach województwa kujawskopomorskiego nie przekroczy $10 \%$ wszystkich gmin. Jeżeli chodzi o opłatę uzdrowiskową, to zaledwie 3 miasta posiadały ją w analizowanym okresie: Ciechocinek, Inowrocław oraz Brześć Kujawski, co stanowi 2,08\% wszystkich gmin i miast województwa kujawsko-pomorskiego. Kolejna hipoteza robocza potwierdziła się w całości.

Stawki opłaty miejscowej i uzdrowiskowej obowiązujące w latach 2010-2014 w poszczególnych gminach województwa kujawsko-pomorskiego przedstawiają poniższe tabele:

Tabela 1. Stawki opłaty miejscowej w gminach województwa kujawsko-pomorskiego w latach 2010-2014.

\begin{tabular}{|l|c|c|c|c|c|}
\hline \multirow{2}{*}{$\begin{array}{c}\text { Gmina / } \\
\text { miasto }\end{array}$} & \multicolumn{5}{|c|}{ Stawka opłaty miejscowej } \\
\cline { 2 - 6 } Tuchola & $1,60 \mathrm{zł}$ & $\begin{array}{c}\text { nie obo- } \\
\text { wiązywała }\end{array}$ & $\begin{array}{c}\text { nie obo- } \\
\text { wiązywała }\end{array}$ & $\begin{array}{c}\text { nie obo- } \\
\text { wiązywała }\end{array}$ & $\begin{array}{c}\text { nie obo- } \\
\text { wiązywała }\end{array}$ \\
\hline Nowe & $1,80 \mathrm{zł}$ & $1,80 \mathrm{zł}$ & $1,90 \mathrm{zł}$ & $\begin{array}{c}\text { nie obo- } \\
\text { wiązywała }\end{array}$ & $\begin{array}{c}\text { nie obo- } \\
\text { wiązywała }\end{array}$ \\
\hline Rogowo & $1,60 \mathrm{zł}$ & $1,60 \mathrm{zł}$ & $1,60 \mathrm{zł}$ & $\begin{array}{c}\text { nie obo- } \\
\text { wiązywała }\end{array}$ & $\begin{array}{c}\text { nie obo- } \\
\text { wiązywała }\end{array}$ \\
\hline $\begin{array}{l}\text { Miasto } \\
\text { Toruń }\end{array}$ & $\begin{array}{c}\text { nie obo- } \\
\text { wiązywała }\end{array}$ & $\begin{array}{c}\text { nie obo- } \\
\text { wiązywała }\end{array}$ & $\begin{array}{c}\text { nie obo- } \\
\text { wiązywała }\end{array}$ & $2,00 \mathrm{zł}$ & $2,00 \mathrm{zł}$ \\
\hline Koronowo & $1,80 \mathrm{zł}$ & $1,80 \mathrm{zł}$ & $1,80 \mathrm{zł}$ & $1,80 \mathrm{zł}$ & $1,80 \mathrm{zł}$ \\
\hline Lubiewo & $1,70 \mathrm{zł}$ & $1,75 \mathrm{zł}$ & $1,75 \mathrm{zł}$ & $1,75 \mathrm{zł}$ & $1,75 \mathrm{zł}$ \\
\hline Osie & $1,50 \mathrm{zł}$ & $1,50 \mathrm{zł}$ & $1,50 \mathrm{zł}$ & $1,50 \mathrm{zł}$ & $1,50 \mathrm{zł}$ \\
\hline Bobrowo & $1,00 \mathrm{zł}$ & $1,00 \mathrm{zł}$ & $1,00 \mathrm{zł}$ & $1,00 \mathrm{zł}$ & $1,00 \mathrm{zł}$ \\
\hline Zbiczno & $1,50 \mathrm{zł}$ & $1,50 \mathrm{zł}$ & $1,50 \mathrm{zł}$ & $2,00 \mathrm{zł}$ & $2,00 \mathrm{zł}$ \\
\hline Chodecz & $1,93 \mathrm{zł}$ & $1,93 \mathrm{zł}$ & $1,93 \mathrm{zł}$ & $1,93 \mathrm{zł}$ & $1,93 \mathrm{zł}$ \\
\hline $\begin{array}{l}\text { Jeziora } \\
\text { Wielkie }\end{array}$ & $1,25 \mathrm{zł}$ & $1,30 \mathrm{zł}$ & $1,35 \mathrm{zł}$ & $1,40 \mathrm{zł}$ & $1,45 \mathrm{zł}$ \\
\hline Żnin & $1,50 \mathrm{zł}$ & $1,50 \mathrm{zł}$ & $1,50 \mathrm{zł}$ & $1,50 \mathrm{zł}$ & $1,50 \mathrm{zł}$ \\
\hline Gąsawa & $1,90 \mathrm{zł}$ & $1,95 \mathrm{zł}$ & $2,00 \mathrm{zł}$ & $2,10 \mathrm{zł}$ & $2,16 \mathrm{zł}$ \\
\hline
\end{tabular}

Źródło: Opracowanie własne na podstawie uchwał poszczególnych rad gminy w sprawie stawek opłaty miejscowej.

w gminie Chodecz w powiecie włocławskim, w gminie Jeziora Wielkie w powiecie mogileńskim oraz w gminach Żnin i Gąsawa w powiecie żnińskim. 
W dziewięciu gminach województwa kujawsko-pomorskiego opłata miejscowa istniała przez cały analizowany okres. W mieście Toruń została wprowadzona w roku 2013, a w pozostałych gminach zrezygnowano z jej poboru - w 2010 r. zrezygnowała Tuchola, a w 2012 r. gminy Nowe i Rogowo. Przyczyną rezygnacji prawdopodobnie były wyższe koszty postępowań oraz poboru opłaty aniżeli wpływy z tytułu tej opłaty. Funkcja fiskalna nie miała większego znaczenia. Jeżeli chodzi o stawki, to zauważamy, iż w większości gmin w ciągu analizowanego okresu, utrzymują się one na tym samym poziomie. W zaledwie w 5 gminach (Nowe, Lubiewo, Zbiczno, Jeziora Wielkie, Gąsawa) stawki opłaty miejscowej wykazywały tendencje rosnące. Najwyższą stawkę w 2014 r. posiadała gmina Gąsawa: na poziomie 2,16 zł za dobę pobytu w miejscowości, w której obowiązywała ta fakultatywna opłata.

Tabela 2. Stawki opłaty uzdrowiskowej w gminach województwa kujawsko-pomorskiego w latach 2010-2014.

\begin{tabular}{|l|c|c|c|c|c|}
\hline \multirow{2}{*}{\multicolumn{1}{|c|}{ Miasto }} & \multicolumn{5}{|c|}{ Stawka opłaty uzdrowiskowej } \\
\cline { 2 - 7 } & 2010 & 2011 & 2012 & 2013 & 2014 \\
\hline Ciechocinek & $3,30 \mathrm{zł}$ & $3,40 \mathrm{zł}$ & $3,50 \mathrm{zł}$ & $3,70 \mathrm{zł}$ & $3,70 \mathrm{zł}$ \\
\hline Inowrocław & $3,00 \mathrm{zł}$ & $3,00 \mathrm{zł}$ & $3,50 \mathrm{zł}$ & $4,00 \mathrm{zł}$ & $4,20 \mathrm{zł}$ \\
\hline Brześć Kujawski & $1,60 \mathrm{zł}$ & $1,60 \mathrm{zł}$ & $1,60 \mathrm{zł}$ & $1,90 \mathrm{zł}$ & $1,90 \mathrm{zł}$ \\
\hline
\end{tabular}

Źródło: Opracowanie własne na podstawie uchwał poszczególnych rad miast w sprawie stawek opłaty uzdrowiskowej.

Jeżeli chodzi o stawki opłaty uzdrowiskowej, to w czasie analizowanego okresu we wszystkich gminach zauważamy tendencję rosnącą. W mieście Ciechocinek i Brześć Kujawski stawki nie rosły aż tak znacząco, podwyżka od 2010 do 2014 r. w mieście Ciechocinek wyniosła 0,40 zł, a w Brześciu Kujawskim zaledwie 0,30 zł pomiędzy rokiem 2012 a 2013. W Inowrocławiu stawka opłaty uzdrowiskowej wykazywała tendencję rosnącą od 2012 r., aż w 2014 r. osiągnęła kwotę 4,20 zł za dobę i zbliżyła się bardzo mocno do stawki wskazanej w tym czasie w ustawie. Trzecia hipoteza robocza potwierdziła się jedynie w stosunku do opłaty uzdrowiskowej, gdzie stawki miały tendencję rosnącą. Natomiast w opłacie miej- 
scowej ta tendencja zwyżkowa występowała jedynie w kilku gminach, gdyż w większości stawka była stawką niezmienną przez cały analizowany okres.

Poniżej zostaną przedstawione wnioski z analizy sprawozdań finansowych wykonania budżetu poszczególnych gmin w analizowanym okresie oraz stosunek procentowy wpływów z opłaty miejscowej i uzdrowiskowej do ogółu dochodów budżetowych.

W mieście Tuchola w powiecie tucholskim opłata miejscowa obowiązywała tylko w 2010 r., a jej stawka na podstawie uchwały Rady Miejskiej w Tucholi z dnia 20 listopada 2009 r. wynosiła 1,60 zł dla osób fizycznych oraz 0,80 zł dla dzieci, młodzieży szkolnej, studentów, emerytów i rencistów. Opłata miejscowa została uchylona w tej jednostce uchwałą Rady Miejskiej w Tucholi z dnia 29 października 2010 r. W roku 2010 z tytułu opłaty miejscowej, przy założeniu wpływów na poziomie 2 000,00 zł, uzyskano kwotę 4 087,80 zł, co stanowiło dwukrotnie więcej niż zakładano w planie (204,40\% wykonania). W stosunku do dochodów budżetowych, które w 2010 r. stanowiły ponad 57 mln zł, opłata miejscowa stanowiła zaledwie 0,007\%. Oznacza to, że pod względem fiskalnym nie miała ona dużego znaczenia, więc organ stanowiący miasta podjął decyzję o jej likwidacji.

W gminie Nowe w powiecie świeckim w latach 2010-2011 opłata miejscowa wynosiła 1,80 zł oraz obowiązywała obniżona stawka $0,90 \mathrm{zł}$ dla niezorganizowanej młodzieży szkolnej oraz emerytów i rencistów. W roku 2012 stawka wynosiła 1,90 zł, a od 2013 r. opłata miejscowa przestała obowiązywać na terenie gminy Nowe. W roku 2010 z tytułu tej opłaty uzyskano 1239,90 zł, co stanowi 30,9\% założonego planu (4 000,00 zł). W 2011 r. dochód wyniósł 990,60 zł, co stanowiło 66\% planu (1 500,00 zł). Natomiast w 2013 r. mimo 1 200,00 zł planowanej kwoty opłaty, dochodu z jej tytułu nie osiągnięto. Dochody w stosunku do budżetu gminy Nowe, który kształtuje się na poziomie 24-26 mln zł, stanowią odpowiednio 0,005\% w roku 2010 oraz 0,004\% w roku 2011. Z punktu widzenia fiskalnego opłata ta nie miała większego znaczenia, więc władze gminy podjęły decyzję o jej niepobieraniu. 
Gmina Rogowo w powiecie świeckim jest szczególnym przypadkiem, w którym współautorka niniejszego artykułu nie uzyskała od pracowników samorządowych w żaden sposób odpowiedzi na pytania, które nasunęły się po analizie uchwał zamieszczonych w BIP. W trakcie badania ustalono, że stawka opłaty miejscowej w latach 2010-2012 wynosiła zgodnie z uchwałą Rady Gminy Rogowo z dnia 11 grudnia 2006 r. 1,60 zł i przez wszystkie lata uchwała ta obowiązywała. W każdym roku budżetowym w budżecie władze gminy planowały uzyskanie dochodów z tytułu tej opłaty w granicach od 1500,00 zł do 2 000,00 zł, jednakże w sprawozdaniach $\mathrm{z}$ wykonania budżetów nie uwzględniono żadnych kwot, które pobrano z tytułu tej opłaty. Z uwagi na powyższe, nasuwa się tutaj bardzo istotna obserwacja: uchwała w gminie Rogowo obowiązuje, a wpływów z opłaty do budżetu nie ma. Czy taka praktyka ma w ogóle sens? Po co istnieją przepisy prawa i opłata na terenie gminy, jeżeli wpływy z jej tytułu nie występują?

W zabytkowym mieście Toruniu, które rocznie odwiedza ponad milion turystów, opłata miejscowa została wprowadzona dopiero w 2013 r. uchwałą Rady Miasta Toruń Nr 430/12 z dnia 22 listopada 2012 r. Stawka w roku 2013 i 2014 utrzymywała się na stałym poziomie 2 zł za każdy dzień pobytu, pod warunkiem że przebywano w Toruniu dłużej niż dobę. Z tytułu wpływów z opłaty miejscowej w roku 2013, przy planowanym dochodzie 200 000,00 zł (wykonanie na poziomie 115,90\%), uzyskano 231783,00 zł, a w 2014 r. przy planie 240 000,00 zł uzyskano 245 295,000 zł (wykonanie 102,20\%). W odniesieniu do ogólnego budżetu, który w Toruniu stanowi ponad 1 mld zł, opłata miejscowa stanowiła odpowiednio 0,022\% dochodów budżetowych w roku 2013 i 0,024\% dochodów budżetowych w roku 2014.

W mieście Koronowo (powiat bydgoski) opłata miejscowa funkcjonowała w latach 2010-2014 na podstawie uchwały Rady Miejskiej Koronowo z dnia 30 września 2009 r., a stawka przez cały analizowany okres wynosiła $1,80 \mathrm{zł}$. W roku $2010 \mathrm{z}$ tytułu opłaty miejscowej osiągnięto kwotę 5 116,10 zł przy kwocie planowanej 3000,00 zł (170,50\% planu), w roku 2011 osiągnięto dochody w wysokości 4 117,45 zł przy planie 4 000,00 zł (102,90\% planu), a w 2012 r. kwota ta przy tym samym planie 
wyniosła 6 980,45 zł (174,50\% planu). W roku 2013 dochody z tytułu tej opłaty były najwyższe w całym analizowanym okresie i wyniosły 7 506,25 zł (150,10\% planu). Rok 2014 przyniósł dochody w wysokości 5 926,90 zł przy kwocie planowanej 5 000,00 zł (118,50\% planu). Na przestrzeni lat dochody z tytułu opłaty miejscowej wynosiły w stosunku do ogółu dochodów budżetowych wartości w przedziale od 0,007\% do 0,011\%.

Gmina Lubiewo w stosunku do pozostałych gmin województwa kujawsko-pomorskiego $\mathrm{z}$ tytułu opłaty miejscowej wykazuje dochody w przedziale od 21 702,75 zł w roku 2014, do nawet 34 873,10 zł w roku 2011. W pozostałych latach dochody kształtowały się następująco: w 2010 r. - kwota 31 343,30 zł, w 2012 r. - kwota 26 004,05 zł, a w 2013 r. - kwota 29 402,74 zł. We wszystkich latach oprócz roku 2014 kwota osiągnięta znacznie przekraczała kwoty planowane przez władze gminy. Dochody budżetowe w gminie Lubiewo z roku na rok ciągle rosły, z prawie 16 mln zł w 2010 r. do ponad 28 mln zł w roku 2014. Wraz ze wzrostem wszystkich dochodów budżetowych stosunek opłaty miejscowej do ogółu dochodów malał, utrzymując się na poziomie 0,20\% w roku 2010, 0,17\% w roku 2011, 0,14\% w roku 2012 i 2013, do 0,08\% w roku 2014.

Na przestrzeni analizowanych lat stawki opłaty miejscowej w gminie Osie w powiecie świeckim regulowała uchwala Rady Gminy Osie z dnia 28 kwietnia 2009 r. na poziomie 1,50 zł. Dochody z tytułu opłaty miejscowej wykazywały w tych latach tendencję malejące. W roku 2010 osiągnięto kwotę 9 118,75 zł, w 2011 r. o tysiąc zł mniej, tj. 8 002,25 zł, w 2012 r. była to kwota 6444,00 zł, natomiast w 2013 r. to już kwota 4 795,50 zł. Niewiele lepiej było w roku 2014, w którym dochód z tytułu opłaty miejscowej osiągnął kwotę 5 803,00 zł. Podobnie jak w pozostałych gminach wpływy z tej opłaty w stosunku do pozostałych dochodów były niewielkie i kształtowały się na poziomie od 0,026\% w roku 2013 do 0,057\% w roku 2010.

Gmina Bobrowo to gmina wiejska położona w powiecie brodnickim, w której budżet kształtował się na poziomie od ponad 18 mln zł w latach 2010-2012 do ok. 21 mln zł w latach 2013-2014. Wpływy z tytułu opłaty miejscowej kształtowały się na poziomie od 120,00 zł w roku 2010 do 
105,50 zł w roku 2011. Należy zaznaczyć, że w roku 2012, mimo planowanej kwoty 901,00 zł, z tytułu tej opłaty nie osiągnięto żadnego dochodu. W stosunku do ogółu dochodów budżetowych wpływy z opłaty miejscowej kształtowały się na poziomie od 0,00065\% do 0,006\%, co świadczy o tym, iż utrzymywanie tej opłaty w gminie Bobrowo nie ma charakteru fiskalnego, lecz ma inne podłoże - pozafiskalne.

W gminie Zbiczno (powiat brodnicki) w każdym analizowanym roku wpływy z opłaty miejscowej przekraczały kwotę planowanego dochodu, którym była kwota 20 000,00 zł. Największy dochód osiągnięto w roku 2010 - wyniósł dokładnie 24 900,00 zł. W kolejnych latach były to następujące kwoty: w roku 2011 - 21 635,00 zł, w 2012 r. - 19 914,50 zł, w 2013 r. - 23 999,00 zł, a w 2014 r. - 20 448,00 zł. Powyższe kwoty w porównaniu do ogólnych dochodów budżetu gminy Zbiczno stanowiły od 0,14\% w latach 2012 i 2014, przez 0,16\% w latach 2011 i 2013 do 0,20\% w roku 2010.

W gminie Chodecz (powiat włocławski) mimo obowiązywania uchwały Rady Miejskiej z dnia 26 listopada 2009 r. w sprawie stawek opłaty miejscowej przedmiotowej opłaty nie pobiera się. W latach 20102014, co wynika z przeanalizowania konkretnych sprawozdań finansowych z wykonania budżetu, z tytułu opłaty miejscowej gmina Chodecz nie osiągnęła żadnych wpływów. Informacja ta została potwierdzona także w rozmowie telefonicznej z pracownikiem Urzędu Gminy Chodecz. W związku z należy zadać sobie pytanie: dlaczego uchwała Rady Gminy nadal obowiązuje, jeżeli nie jest wykonywana przez władze samorządowe?

W gminie Jeziora Wielkie w powiecie mogileńskim obowiązywały w każdym okresie uchwały w sprawie stawek opłaty miejscowej. Tabela nr 1 wskazuje, jak te stawki kształtowały się w analizowanym okresie. Jednakże po analizie sprawozdań finansowych, zauważono, że tylko w roku 2011 gmina uzyskała z tytułu tej opłaty dochód w wysokości 10 553,20 zł, co w odniesieniu do ogólnego budżetu wynoszącego w tym roku ok. 14,5 mln zł stanowiło zaledwie 0,073\%. W pozostałych latach w sprawozdaniach finansowych władze gminy nie wykazywały dochodu z tytułu opłaty miejscowej, mimo kwot planowanych na poziomie ponad 10 tys. zł. 
W latach 2010-2014 w mieście Żnin obowiązywała uchwała Rady Miasta Żnin z dnia 5 grudnia 2003 r. w sprawie stawek opłaty miejscowej, w której ustalono, iż stawka ta wynosić będzie 1,50 zł oraz 0,75 zł dla dzieci i młodzieży uczącej się. Kwoty uzyskiwane z tytułu tej opłaty były znikome i nie przekraczały 110 zł we wszystkich latach. Opłata ta stanowiła zaledwie 0,00011\% do 0,00017\% w skali wszystkich dochodów budżetowych. Z tego głównie powodu Rada Miejska w Żninie w 2 grudnia 2015 r. podjęła uchwałę o uchyleniu uchwały poprzednio obowiązującej i tym samym od 2016 r. zlikwidowała opłatę miejscową na swoim terenie.

W gminie Gąsawa (powiat żniński) z roku na rok stawka opłaty miejscowej rosła, osiągając w roku 2014 wartość 2,16 zł dziennie. Jednakże wraz ze wzrostem stawki dochody z tytułu tej opłaty malały. W roku 2010 uzyskano kwotę 11 932,40 zł, w 2011 r. była to kwota nieco niższa 11 181,00 zł, a w 2012 r. wyniosła 9 120,00 zł. Najwyższy spadek odnotowano w 2013 r., kiedy wpływy przekroczyły kwotę 6 800,00 zł. Natomiast w 2014 r. uzyskano zaledwie 8 484,20 zł z tytułu opłaty miejscowej. Jeżeli chodzi o wpływy z tytułu tej opłaty na budżet ogólny, to jest on niewielki, gdyż w analizowanym okresie stanowi od 0,039\% w roku 2013 do $0,077 \%$ w roku 2011.

Opłata uzdrowiskowa w latach 2010-2014 istniała zaledwie w 3 miastach województwa kujawsko-pomorskiego: Ciechocinku, Inowrocławiu oraz Brześciu Kujawskim. Poniżej przedstawione zostaną wnioski z badania empirycznego w zakresie dochodów uzyskanych z tytułu opłaty uzdrowiskowej.

W Inowrocławiu opłata uzdrowiskowa stanowi dość istotną opłatę lokalną z punktu widzenia fiskalnego. Wpływy z tej opłaty znacząco przekraczają kwotę $1 \mathrm{mln}$ zł. W każdym roku kwota uzyskana z tej opłaty przekraczała kwoty wskazane w planie finansowym. W roku 2010 uzyskano z jej tytułu kwotę 1211 374,00 zł, co stanowiło 0,58\% ogółu dochodów budżetowych. W roku 2011 kwota ostateczna wyniosła 1141 599,00 zł, co stanowiło 0,50\% ogółu dochodów miasta Inowrocław. Od 2012 r. wpływy budżetowe z opłaty uzdrowiskowej zaczęły znacząco rosnąć. W roku 2012 osiągnięto dochód w wysokości 1427 376,70 zł, co stanowiło 0,63\% ogółu dochodów. 2013 r. przyniósł kwotę w wysokości 
1632 287,00 zł, co stanowiło 0,76\%, a w 2014 r. wpływy z opłaty miejscowej osiągnęły niebagatelną kwotę 1866345,20 zł, co stanowiło 0,81\%. Jak widać, opłata uzdrowiskowa nie przekraczała kwoty 2 mln zł, ale uzyskane fundusze mogą być wykorzystane na realizację wielu zadań inwestycyjnych na terenie miasta, które posłużą przyciągnięciu do niego kolejnych turystów. Poniższa tabela przedstawia analizę dochodów budżetowych w mieście Inowrocław.

Tabela 3. Analiza dochodów budżetowych miasta Inowrocław oraz wpływów z opłaty uzdrowiskowej w latach 2010-2014.

\begin{tabular}{|c|c|c|c|c|c|}
\hline Inowrocław - opłata & \multicolumn{5}{|c|}{ Rok budżetowy } \\
\cline { 2 - 6 } uzdrowiskowa & 2010 & 2011 & 2012 & 2013 & 2014 \\
\hline $\begin{array}{c}\text { Dochody uzyskane } \\
\text { z opłaty }\end{array}$ & $\begin{array}{c}1211374,00 \\
\text { zł }\end{array}$ & $\begin{array}{c}1141599,00 \\
\text { zł }\end{array}$ & $\begin{array}{c}1427376,70 \\
\text { zł }\end{array}$ & $\begin{array}{c}1632287,00 \\
\text { zł }\end{array}$ & $\begin{array}{c}1866345,20 \\
\text { zł }\end{array}$ \\
\hline $\begin{array}{c}\text { Dochody budżetowe } \\
\text { ogółem }\end{array}$ & $\begin{array}{c}206888195,64 \\
\text { zł }\end{array}$ & $\begin{array}{c}226870255,62 \\
\text { zł }\end{array}$ & $\begin{array}{c}224944304,26 \\
\text { zł }\end{array}$ & $\begin{array}{c}213258978,45 \\
\text { zł }\end{array}$ & $\begin{array}{c}230343009,32 \\
\text { zł }\end{array}$ \\
\hline $\begin{array}{c}\text { \% opłaty w stosunku } \\
\text { do dochodów }\end{array}$ & $0,58 \%$ & $0,50 \%$ & $0,63 \%$ & $0,76 \%$ & $0,81 \%$ \\
\hline
\end{tabular}

Źródło: Opracowanie własne na podstawie sprawozdań z wykonania budżetu Miasta Inowrocław.

Miasto Ciechocinek z uwagi na dużą liczbę sanatoriów i uzdrowisk jest niejako pionierem w województwie kujawsko-pomorskim, jeżeli chodzi o pobór opłaty uzdrowiskowej. Uzyskane kwoty znacząco przekraczają 3 mln zł, a w latach 2013-2014 nawet 4 mln zł. Wykazują one cały czas tendencję rosnącą. W tym samym okresie rosły też stawki opłaty uzdrowiskowej, więc to też może mieć istotne znaczenie na ostateczną kwotę dochodów z tytułu tej opłaty. W stosunku do ogółu dochodów budżetowych wpływy z opłaty uzdrowiskowej kształtują się na poziomie od 8,64\% w roku 2010 do 9,96\% w roku 2014. Opłata uzdrowiskowa w tej gminie ma przede wszystkich charakter fiskalny, gdyż stosunek wpływów z tej opłaty do ogółu dochodów budżetowych jest dość znaczący. Poniższa tabela przedstawia dochody uzyskane $\mathrm{z}$ opłaty uzdrowiskowej oraz ich stosunek do ogółu dochodów budżetowych. 
Tabela 4. Analiza dochodów budżetowych miasta Ciechocinek oraz wpływów z opłaty uzdrowiskowej w latach 2010-2014.

\begin{tabular}{|c|c|c|c|c|c|}
\hline \multirow{2}{*}{$\begin{array}{l}\text { Ciechocinek - } \\
\text { opłata uzdrowi- } \\
\text { skowa }\end{array}$} & \multicolumn{5}{|c|}{ Rok budżetowy } \\
\hline & 2010 & 2011 & 2012 & 2013 & 2014 \\
\hline $\begin{array}{l}\text { Dochody uzyska- } \\
\text { ne z opłaty }\end{array}$ & $\begin{array}{c}3065835,75 \\
\text { zł }\end{array}$ & $\begin{array}{c}3429564,70 \\
\mathrm{zł}\end{array}$ & $\begin{array}{c}3653157,55 \\
\mathrm{zł}\end{array}$ & $\begin{array}{c}4070755,42 \\
\text { zł }\end{array}$ & $\begin{array}{c}4218891,97 \\
\text { zł }\end{array}$ \\
\hline $\begin{array}{l}\text { Dochody budże- } \\
\text { towe ogółem }\end{array}$ & $\begin{array}{c}35443465,90 \\
\text { zł }\end{array}$ & $\begin{array}{c}39473417,75 \\
z ł\end{array}$ & $\begin{array}{c}39973599,39 \\
\text { zł }\end{array}$ & $\begin{array}{c}42482529,83 \\
\text { zł }\end{array}$ & $\begin{array}{c}42366797,07 \\
\text { zł }\end{array}$ \\
\hline $\begin{array}{c}\text { \% opłaty w sto- } \\
\text { sunku do docho- } \\
\text { dów }\end{array}$ & $8,64 \%$ & $8,69 \%$ & $9,14 \%$ & $9,58 \%$ & $9,96 \%$ \\
\hline
\end{tabular}

Źródło: Opracowanie własne na podstawie sprawozdań z wykonania budżetu Miasta Ciechocinek.

W mieście Brześć Kujawski w powiecie włocławskim wpływy z opłaty uzdrowiskowej w analizowanym okresie znacząco przekraczają 100 tys. zł. Najwięcej dochodu Brześć Kujawski uzyskał w latach 2010 oraz 2013, kiedy wpływy z opłaty miejscowej przekroczyły 147 tys. zł. W stosunku do ogółu dochodów budżetowych, które w Brześciu Kujawskim kształtują się na poziomie 35-38 mln zł, wpływy z opłaty uzdrowiskowej stanowiły odpowiednio $0,29 \% \mathrm{w}$ roku 2014 do $0,41 \% \mathrm{w}$ roku 2013. W porównaniu do Inowrocławia, a w szczególności do Ciechocinka, wpływy tej opłaty do budżetu nie są znaczące. Poniższa tabela przedstawia szczegółowo analizę dochodów i wpływów z opłaty uzdrowiskowej w analizowanym mieście.

Tabela 5. Analiza dochodów budżetowych miasta i gminy Brześć Kujawski oraz wpływów z opłaty uzdrowiskowej w latach 2010-2014.

\begin{tabular}{|c|c|c|c|c|c|}
\hline \multirow{2}{*}{$\begin{array}{c}\text { Brześć Kujaw- } \\
\text { ski - opłata } \\
\text { uzdrowiskowa }\end{array}$} & \multicolumn{5}{|c|}{ Rok budżetowy } \\
\hline & 2010 & 2011 & 2012 & 2013 & 2014 \\
\hline $\begin{array}{l}\text { Dochody uzy- } \\
\text { skane z opłaty }\end{array}$ & $147121,80 \mathrm{zł}$ & $127737,60 \mathrm{zł}$ & $129342,40 \mathrm{zf}$ & $147411,50 \mathrm{zł}$ & 114 647,90 zł \\
\hline $\begin{array}{l}\text { Dochody bu- } \\
\text { dżetowe ogółem }\end{array}$ & $\begin{array}{c}37075745,65 \\
\text { zł }\end{array}$ & $\begin{array}{c}35357982,40 \\
\text { zł }\end{array}$ & $\begin{array}{c}38949171,72 \\
\text { zł }\end{array}$ & $\begin{array}{c}35593171,72 \\
\text { zł }\end{array}$ & $\begin{array}{c}38846425,80 \\
\text { zł }\end{array}$ \\
\hline
\end{tabular}




\begin{tabular}{|c|c|c|c|c|c|}
\hline $\begin{array}{c}\text { \% opłaty } \\
\text { w stosunku do } \\
\text { dochodów }\end{array}$ & $0,40 \%$ & $0,36 \%$ & $0,33 \%$ & $0,41 \%$ & $0,29 \%$ \\
\hline
\end{tabular}

Źródło: Opracowanie własne na podstawie sprawozdań z wykonania budżetu Miasta i Gminy Brześć Kujawski.

W kolejnej hipotezie roboczej współautorka niniejszego artykułu założyła, że dochody osiągnięte przez poszczególne gminy w latach 20102014 z tytułu omawianych opłat lokalnych nie przekraczały 1\% wszystkich dochodów budżetowych. Hipoteza ta potwierdziła się, lecz miasto Ciechocinek stanowi jeden dość istotny wyjątek. W Ciechocinku w analizowanym okresie wpływy z opłaty uzdrowiskowej w stosunku do ogółu dochodów budżetowych kształtowały się zawsze na poziomie od 8,64\% do $9,96 \%$. W pozostałych gminach wartości te było o wiele mniejsze, szczególnie jeżeli chodzi o wpływy z opłaty miejscowej.

\section{Podsumowanie}

Opłata miejscowa i uzdrowiskowa to dwie fakultatywne daniny publiczne, których wprowadzenie na terenie danej gminy wymaga spełnienia określonych warunków wskazanych przez ustawodawcę w przepisach prawa powszechnie obowiązującego. Wprowadzając daną opłatę lokalną na teren gminy, władze powinny brać pod uwagę fakt, czy jej obowiązywanie nie będzie rodziło dla samorządu zbyt wysokich kosztów funkcjonowania. Organ stanowiący gminy musi uprzednio zweryfikować jej opłacalność ze względów finansowych, uwzględniając przy tym nie tylko cele fiskalne, ale także biorąc pod uwagę cele pozafiskalne ${ }^{31}$.

Po przeprowadzonym badaniu empirycznym w gminach województwa kujawsko-pomorskiego, w którym obowiązują analizowane opłaty, można dojść do wniosku, iż w większości gmin opłaty te stanowią znikome źródło dochodów własnych. Ich obowiązywanie w poszczególnych gminach na pewno nie ma charakteru fiskalnego, a jedynie opłaty te obo-

31 R. Dowgier, L. Etel, B. Pahl, M. Popławski, Podatki i opłaty lokalne. 601 pytań i odpowiedzi, Warszawa 2012, s. 659. 
wiązują z uwagi na inne cele pozafiskalne. W ten sposób potwierdza się ostatnia hipoteza robocza współautorki artykułu, która wskazywała, że opłata miejscowa i uzdrowiskowa w gminach województwa kujawsko-pomorskiego spełnia jedynie funkcje pozafiskalne.

Wpływy nieprzekraczające kilku tys. zł powinny zmusić władze gminy do przeanalizowania sytuacji i zastanowienia się nad rezygnacją z poboru tak nieefektywnej z punktu widzenia fiskalnego opłaty lokalnej. Wyniki badań potwierdziły, że w większości gmin dochody z tytułu tych opłat są znikome. Jedynym wyjątkiem jest miasto Ciechocinek, gdzie wpływy z opłaty uzdrowiskowej znacząco przekraczają kwotę 3-4 mln zł. Biorąc powyższe pod uwagę, należy zastanowić się nad pytaniem: jaki sens ma funkcjonowanie w katalogu opłat lokalnych daniny publicznej, która nie przynosi do budżetu znaczących wpływów, a jedynie generuje koszty związane z jej obowiązywaniem?

\section{Bibliografia:}

Borodo A., Polskie prawo finansowe. Zarys ogólny, TNOiK, Toruń 2007.

Borszowski P., Ustawa o podatkach i opłatach lokalnych. Komentarz, Lexis Nexis, Warszawa 2011.

Borszowski P., Stelmaszczyk K., Podatki i opłaty lokalne. Podatek rolny. Podatek leśny. Komentarz, Wolters Kluwer, Warszawa 2016.

Dowgier R. Obowiqzzek uiszczenia opłaty uzdrowiskowej. Glosa do wyroku WSA w Bydgoszczy z 27 kwietnia 2011 roku (I SA/Bd 76/11), „Finanse Komunalne” 2011, nr 7-8, s. 116-122.

Dowgier R., Etel L., Podatki i opłaty lokalne. Czas na zmiany, Temida 2, Białystok 2013.

Dowgier R., Etel L., Pahl B., Popławski M., Podatki i opłaty lokalne. 601 pytań i odpowiedzi, LEX a Wolters Kluwer business, Warszawa 2012.

Dudar G., Opłata uzdrowiskowa - problemy praktyczne, „Przegląd Podatków Lokalnych i Finansów Samorządowych” 2006, nr 6, s. 8-17.

Dudar G., Komentarz do art. 17 ustawy o podatkach i opłatach lokalnych, [w:] L. Etel, S. Presnarowicz, G. Dudar, Podatki i opłaty lokalne. Podatek rolny. Podatek leśny. Komentarz, ABC a Wolters Kluwer business, Warszawa 2008. 
Łobocki M., Wprowadzenie do metodologii badań pedagogicznych, Oficyna Wydawnicza Impuls, Kraków 2007.

Olesińska A., Polskie prawo podatkowe. Zarys systemu, TNOiK „Dom Organizatora”, Toruń 2007.

Sienkiewicz A., Opłata miejscowa, „Biuletyn Skarbowy” 2008, nr 1, s. 11-13.

Morawski W., Wantoch-Rekowski J., Komentarz do art. 17 ustawy o podatkach i opłatach lokalnych, [w:] W. Morawski (red.), Ustawa o podatkach i opłatach lokalnych. Komentarz, Gdańsk 2013.

Morawski W., Wantoch-Rekowski J., Komentarz do art. 19 ustawy o podatkach i opłatach lokalnych, [w:] W. Morawski (red.), Ustawa o podatkach i opłatach lokalnych. Komentarz, ODDK, Gdańsk 2013.

Wantoch-Rekowski J., Opłata uzdrowiskowa a pobyt w szpitalu uzdrowiskowym - uwagi na tle interpretacji ogólnej ministra finansów, „Prawo Budżetowe Państwa i Samorządu” 2016, nr 1, s. 33-41. 